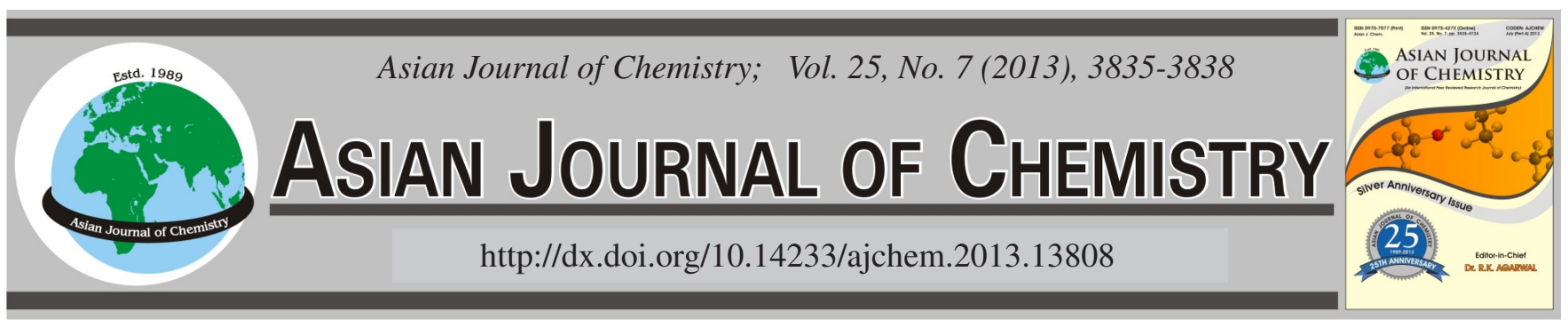

\title{
Biological Activities of Herbaceous Peony Flower Extracts
}

\author{
Ying-Shan Jin ${ }^{1}$, Yong-Hao Xunan ${ }^{2}$, Yin-Zhe Jin ${ }^{3}$, Man-Li Chen $^{1}$ and Jun TaO ${ }^{4, *}$
}

${ }^{1}$ College of Bioscience and Biotechnology, Yangzhou University, Yangzhou 225009, Jiangsu Province, P.R. China

${ }^{2}$ Yangzhou University Library, Yangzhou University, Yangzhou 225009, Jiangsu Province, P.R. China

${ }^{3}$ College of Food Science and Technology, Shanghai Ocean University, Shanghai 201306, P.R. China

${ }^{4}$ College of Horticulture and Plant Protection, Yangzhou University, Yangzhou 225009, Jiangsu Province, P.R. China

*Corresponding author: E-mail: taojun@yzu.edu.cn

\begin{abstract}
Herbaceous peony (Paeonia lactiflora Pall.) root is an important Traditional Chinese Medicine. To determine if the flower has any beneficial properties, we investigated antioxidant, antiinflammatory and anti $\alpha$-glucosidase activities of petroleum ether, ethyl ether, ethyl acetate, $n$-butanol and water extracts of herbaceous peony flower. Antioxidant activity was evaluated by measuring total phenolic content, total antioxidant activity and DPPH radical scavenging activities. The ethyl ether and ethyl acetate extracts exhibited higher antioxidant ability than the other extracts. Moreover, the ethyl ether and ethyl acetate extracts had greater antiinflammatory activity on murine macrophage cells (RAW264.7). On the other hand, the petroleum ether extract and ethyl acetate extract showed strong inhibitory effect on $\alpha$-glucosidase. These results suggest that flower from Herbaceous peony may have health-enhancing effects.
\end{abstract}

Key Words: Paeonia lactiflora Pall. Flower, Antioxidant activity, Anti $\alpha$-glucosidase, Antiinflammatory.

\section{INTRODUCTION}

Herbaceous peony (Paeonia lactiflora Pall.) root is an important Traditional Chinese Medicine (TCM). A decoction of the root has been used in the treatment of rheumatoid arthritis, systemic lupus erythematosus, hepatitis, dysmenorrhea, muscle cramping and spasms and fever with a long history. Herbaceous peony is rich in different kinds of bioactive components, such as monoterpenes ${ }^{1-3}$, triterpenes ${ }^{4,5}$, flavonoids ${ }^{5,6}$, stilbenes $^{7}$, volatile oil ${ }^{5}$ and polyphenols ${ }^{8-10}$, among which paeoniflorin a kind of monoterpene is the most studied medicinal compound ${ }^{2,11-13}$. During the cultivation of medicinal herbaceous peony, above ground biomass is often discarded as litter, resulting in enormous waste of resources.

In recent years, much attention has been focused on the biological properties of natural herbs and foods ${ }^{14,15}$. Many important bioactivities (such as antioxidant, antiinflammatory, antidiabetes, anticancer) have been investigated in plant. Biological activities are correlated to the presence of certain compounds that may assist in predicting some traditional uses of medicinal plants ${ }^{16}$. Thus, we can assume that some plants can be less toxic to humans and can be used as medicine for the treatment of diseases. Previous studies of herbaceous peony were mainly focused on the $\operatorname{root}^{2,10,12,17}$, with monoterpenes as the main compounds. There were few reports about the above ground parts of herbaceous peony.
In this study, we evaluated the possible biological activities such as antioxidant, anti $\alpha$-glucosidase, antiinflammatory activities of flowers from herbaceous peony.

\section{EXPERIMENTAL}

Plant material and preparation of extracts: Herbaceous peony flower were collected from Yangzhou and identified by Professor Jun Tao (College of Horticulture and Plant Protection, Yangzhou University, China). Herbaceous peony flower was dried in the shade at room temperature and a $200 \mathrm{~g}$ sample of the powder was subjected to a methanol extraction process for $3 \mathrm{~d}$. The extract was filtered through filter paper $(100 \mathrm{~mm}$; Whatman, Maidstone, UK) and evaporated using a vacuum rotary evaporator (CCA-1110; Eyela, Tokyo, Japan) to produce a crude extract of $108.7 \mathrm{~g}$. The crude extract was suspended in $500 \mathrm{~mL}$ deionized water and partitioned sequentially with $500 \mathrm{~mL}$ of petroleum ether, $500 \mathrm{~mL}$ of ethyl ether, $500 \mathrm{~mL}$ of ethyl acetate and $500 \mathrm{~mL}$ of $n$-butanol. The solvent of petroleum ether fraction, ethyl ether fraction, ethyl acetate fraction and $n$-butanol fraction was then evaporated using a vacuum rotary evaporator. The final yields of petroleum ether fraction (PEF), ethyl ether fraction (EEF), ethyl acetate fraction (EAF), $n$-butanol fraction $(\mathrm{BF})$ and water fraction (WF) were 6.92, 22.28, 21.12, 12.18 and $35.9 \%$, respectively (Table-1). 


\begin{tabular}{lccc}
\hline \multicolumn{4}{c}{ TABLE-1 } \\
YIELD, TOTAL PHENOLIC AND DPPH FREE \\
RADICAL SCAVENGING ACTIVITY OF EXTRACTS \\
FROM Paeonia lactiflora PALL. FLOWERS
\end{tabular}

Determination of total phenolic contents: Each extract $(1 \mathrm{~mL}, 1 \mathrm{mg} / \mathrm{mL})$ was mixed with $9 \mathrm{~mL}$, reagent solution $(0.1 \mathrm{~N}$ Folin-Ciocalteu reagent and $7.5 \%$ sodium carbonate). The reaction mixture was incubated at room temperature for $0.5 \mathrm{~h}$ against a blank. The total phenolic content was determined with respect to the standard curve of tannic acid and was expressed as tannic acid equivalent ${ }^{18}$.

Total antioxidant activity: The effects of herbaceous peony flower extracts on total antioxidant were investigated according to the method of Prieto et al. ${ }^{19}$, with several modifications. Briefly, $0.2 \mathrm{~mL}$ of each extract (at concentration of $12.5 \mu \mathrm{g} / \mathrm{mL}$ ) was mixed with $0.6 \mathrm{~mL}$ of the reagent solution (0.6 M sulphuric acid, $28 \mathrm{mM}$ sodium phosphate and $4 \mathrm{mM}$ ammonium molybdate). The reaction mixture was incubated at $95{ }^{\circ} \mathrm{C}$ for $90 \mathrm{~min}$. The absorbance of the cooled mixture was measured at $695 \mathrm{~nm}$ against a blank. The total antioxidant activity was expressed as the absorbance of the sample. The higher absorbance value indicates higher antioxidant activity. Paeoniflorin and BHT were used as standards.

DPPH radical scavenging activity: The free radical scavenging activities of the extracts, based on the scavenging activity of the stable 1,1-diphenyl-2-picrylhydrazyl (DPPH) free radical, were determined by Kilani et $a l .{ }^{20}$, with some modifications. Aliquots $(0.5 \mathrm{~mL})$ of varying concentration of the extract were mixed with freshly prepared DPPH in methanol (final concentration $250 \mu \mathrm{M}$ ) and the absorbance at $517 \mathrm{~nm}$ was determined after incubation for $0.5 \mathrm{~h}$ in the dark at room temperature. Distilled water was used as control and ascorbic acid as reference compound. Each dilution was assayed in triplicate, the three readings were averaged and the percentage inhibition of activity was calculated as: $\left(1-\mathrm{A}_{\text {sample }} / \mathrm{A}_{\text {control }}\right) \times$ $100 \%$

Protection from protein damage: The effect of different fractions on protein oxidation was carried out according to the method of Hu et al. ${ }^{21}$ with some modifications. One hundred microliters of $4 \mathrm{mg} / \mathrm{mL}$ bovine serum albumin (BSA) was mixed with $100 \mu \mathrm{L}$ of $\mathrm{H}_{2} \mathrm{O}$ or $1 \mathrm{mg} / \mathrm{mL}$ different extracts. The mixture was incubated at $37{ }^{\circ} \mathrm{C}$ for $3 \mathrm{~h}$ with $300 \mu \mathrm{L}$ reagent solution $\left(50 \mu \mathrm{M} \mathrm{FeCl}_{3}, 1 \mathrm{mM} \mathrm{H}_{2} \mathrm{O}_{2}\right.$ and $100 \mu \mathrm{M}$ ascorbic acid). Bovine serum albumin without Fenton's reagent was used as the positive control. After incubation, the mixture was mixed with loading buffer and further incubated at $95^{\circ} \mathrm{C}$ for $10 \mathrm{~min}$. After treatment, protein samples were subjected to SDS-polyacrylamide gel electrophoresis (SDS-PAGE) to quantify protein damage. The protein sample was loaded in a $12 \%$ polyacrylamide gel and electrophoresed. After running for $2 \mathrm{~h}$, gels were stained with $0.15 \%$ Coomassie brilliant blue R-250 for $12 \mathrm{~h}$, washed for $24 \mathrm{~h}$. Densitometric analysis was done with image analysis software (Quantity one; Bio-Rad, Hercules, CA).

Rat intestinal $\alpha$-glucosidase inhibitory activity: $\alpha$-Glucosidase inhibitory activity was assayed by Kim et al. ${ }^{22}$ with some modifications. $\alpha$-Glucosidase (0.075 unit) was mixed with various concentrations $(0.01-200 \mu \mathrm{g} / \mathrm{mL})$ of herbaceous peony flower extracts in phosphate buffer. After 15 min preincubation at $37^{\circ} \mathrm{C}, 100 \mu \mathrm{L}$ of $3 \mathrm{mM} p$-nitrophenyl glucopyranoside ( $p$ NPG) was added to the mixtures as substrate. The reactions were incubated at $37^{\circ} \mathrm{C}$ for $10 \mathrm{~min}$ and stopped by adding $750 \mu \mathrm{L}$ of $0.1 \mathrm{M} \mathrm{Na}_{2} \mathrm{CO}_{3}$. $\alpha$-Glucosidase activity was determined by measuring the $p$-nitrophenol released from the $p$-nitrophenyl glucopyranoside at $405 \mathrm{~nm}$.

Cell lines and cell culture: Mutine macrophage RAW264.7 cell line were purchased from the Korean Cell Bank (Seoul, Korea) and grown in Roswell Park Memorial Institute medium 1640 (RPMI 1640), supplemented with $10 \%$ fetal bovine serum, $100 \mathrm{U} / \mathrm{mL}$ penicillin and $100 \mu \mathrm{g} / \mathrm{mL}$ streptomycin. Cells were cultured in a humidified atmosphere and incubated at $37^{\circ} \mathrm{C}$ in $5 \% \mathrm{CO}_{2}$.

Nitric oxide assay: After pre-incubation of RAW264.7 cells $\left(2 \times 10^{6}\right.$ cells $\left./ \mathrm{mL}\right)$ with LPS $(1 \mu \mathrm{g} / \mathrm{mL})$ for $24 \mathrm{~h}$, the quantity of nitrite in the culture medium was measured as an indicator of NO production. Aliquots of $100 \mu \mathrm{L}$ cell culture medium were mixed with $50 \mu \mathrm{L}$ of $1 \%$ sulfanilamide (in $5 \%$ phosphoric acid) and $50 \mu \mathrm{L}$ of $0.1 \%$ naphthyl-ethylenediamine dihydrochloride. Subsequently, the mixture was incubated at room temperature for $10 \mathrm{~min}$ and the absorbance was measured at $550 \mathrm{~nm}$.

MTT assay for measurement of cell proliferation: The cytotoxicity of herbaceous peony flower extracts was determined by a conventional MTT assay, as previously reported ${ }^{23}$.

Statistical analyses: All tests were carried out independently in triplicate $(n=3)$. Data are expressed as the mean \pm standard derivation (SD). The results were processed using Excel 2003 (Microsoft, Redmond, WA, USA).

\section{RESULTS AND DISCUSSION}

Total phenolic contents: Antioxidant compounds can reduce the risk of many diseases, such as diabetes, inflammation, cancer, several degenerative diseases and aging ${ }^{24}$. Carotenoids, ascorbic acid, flavonoids and phenolic acids might be some of the components able to contribute to their antioxidant activity ${ }^{25}$. The total phenolic contents of herbaceous peony flower extracts are shown in Table-1. The order of total phenolic contents was: $\mathrm{PEF}$ EEF $>>$ EAF $>$ BF $>$ WF. EEF and EAF exhibited higher phnolic contents (42.59 and 33.70 $\mathrm{mg} / \mathrm{g}$ ) than BF and WF (2.97 and $1.19 \mathrm{mg} / \mathrm{g}$ ). These results imply that herbaceous peony flower extracts EEF and EAF contain considerable amounts of phenolics.

Total antioxidant activity: High absorbance value of a sample indicates high antioxidant activity (Fig. 1). All sample exhibited varying degrees of antioxidant activity. The order of total antioxidant activity was: Paeoniflorin $>$ EAF $>$ EEF $>$ 


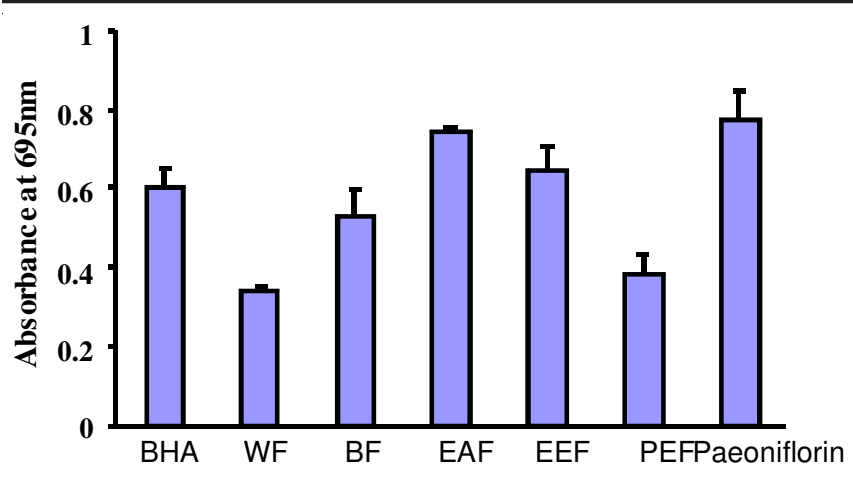

Fig. 1. Total antioxidant activity of extracts of herbaceous peony flower $(12.5 \mu \mathrm{g} / \mathrm{mL})$. Paeoniflorin and BHA were used as standards

BHA > BF > PEF > WF. At $12.5 \mu \mathrm{g} / \mathrm{mL}$, Paeoniflorin, EAF and EEF showed higher total antioxidant activity than BHA.

DPPH radical scavenging activity: It was reported that DPPH is the method of choice for evaluating the free radical scavenging activity of natural compounds ${ }^{26}$. The DPPH radical scavenging activities of different extracts are shown in Table-1. The order of DPPH radical scavenging activity was: EAF > EEF $>$ PEF $>$ BF $>$ WF. The DPPH scavenging activities of the extracts, expressed as an $\mathrm{IC}_{50}$ value, ranged from 4.70$273.12 \mu \mathrm{g} / \mathrm{mL}$. The EAF exhibited the strongest antioxidant activity $\left(\mathrm{IC}_{50}\right.$ value of $4.70 \mu \mathrm{g} / \mathrm{mL}$ ), followed by the $\mathrm{EEF}\left(\mathrm{IC}_{50}\right.$ value of $7.31 \mu \mathrm{g} / \mathrm{mL}$ ) and the $\mathrm{PEF}$ and $\mathrm{BF}\left(\mathrm{IC}_{50}\right.$ value of 42.44 and $44.89 \mu \mathrm{g} / \mathrm{mL}$ ) which showed the weakest activity. These results suggested that the EAF and EEF contained the strongest free radical scavenging compounds.

Protection against protein damage: The oxidative protein damage induced by free radicals has been shown to play a significant role in aging and in several pathological events ${ }^{27}$. Hydroxyl radical is recognized as a protein-damaging agent with physiological significance. In the present study, protein damage was induced by the $\mathrm{Fe}^{3+} / \mathrm{H}_{2} \mathrm{O}_{2} /$ ascorbic acid system. The density of the bovine serum albumin band decreased to than that of the control after incubation with the Fenton's reagent (Fig. 2). The herbaceous peony flower extracts restored the bovine serum albumin band intensity, EAF and EEF showed greater protein protection than $\mathrm{WF}, \mathrm{BF}$ and $\mathrm{PEF}$.

A

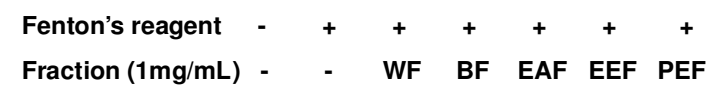

B

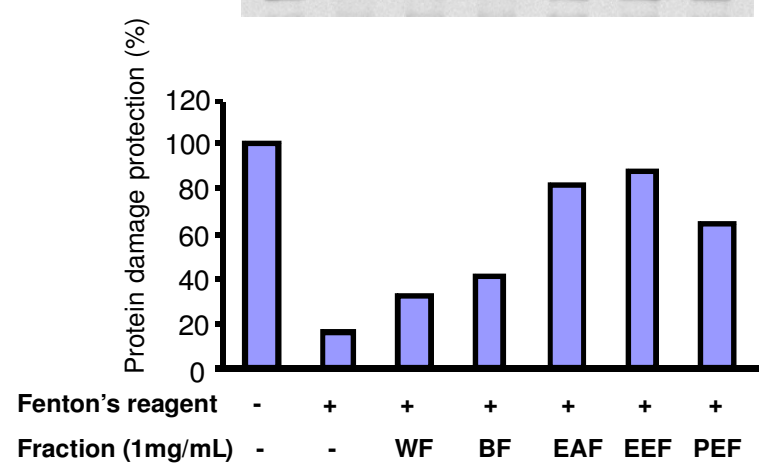

Fig. 2. (A) SDS-PAGE profile of the BSA protein treated with $\mathrm{Fe}^{3+} / \mathrm{H}_{2} \mathrm{O}_{2} /$ ascorbic acid system in the presence of the fractions of herbaceous peony flower $(1 \mathrm{mg} / \mathrm{mL})$. (B) Histogram showing the protective effect densitometric measurements
Antiinflammatoty activity: Inflammation is a complex biological response to pathogens and damaged cells. However, chronic and uncontrolled inflammation may serve as an important and common pattern in various diseases ${ }^{28}$. Therapy of inflammatory diseases is usually directed at the inflammatory processes. Many antiinflammatory drugs have been prepared and marketed ${ }^{29}$; however, these complex drugs are known to provoke gastrointestinal irritation. Thus, more gentle antiinflammatory natural herbs are being investigated. In present study, the antiinflammatory activity of herbaceous peony flower extracts was measured on lipopolysaccharide (LPS)induced RAW264.7 cells. LPS can activate immune cells to upregulate inflammatory states. The level of nitric oxide (NO) produced is an important indicator of the inflammatory process. The overproduction of NO can create cytotoxicity and tissue damage in an organism ${ }^{30}$. Compared to the group with LPS treatment, the herbaceous peony flower EAF and EEF reduced NO product (Fig. 3A). LPS can induce apoptosis in the cells, with a viability of $61.99 \%$ (Fig. 3B). Herbaceous peony flower extracts protected the cells against LPS-induced apoptosis. The antiinflammatory effect of herbaceous peony flower EAF and EEF is considerable, the results suggest that herbaceous peony flower EAF and EEF is suitable to be used as an antiinflammatory agent. The molecular mechanism of the antiinflammatory effect elicited by herbaceous peony flower will be investigated in further study.
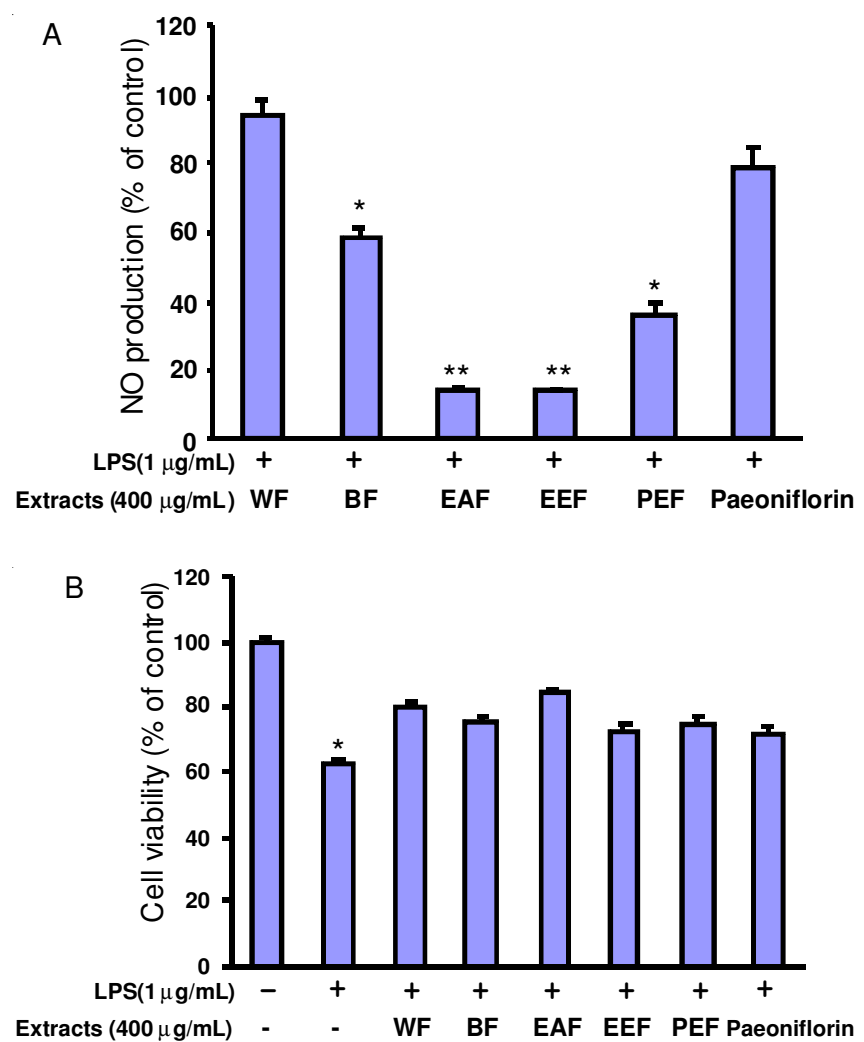

Fig. 3. Effect of herbaceous peony flower extracts on production of $\mathrm{NO}$ in LPS-activated RAW264.7 cells. (A) RAW264.7 cells $\left(1 \times 10^{6}\right.$ cells/ $\mathrm{mL})$ were incubated with herbaceous peony flower extracts in the presence of LPS $(1 \mu \mathrm{g} / \mathrm{mL})$ for $24 \mathrm{~h}$. Culture supernatants were assayed for NO determination by Griess assay. (B) RAW264.7 cells $\left(1 \times 10^{6}\right.$ cells $\left./ \mathrm{mL}\right)$ were incubated with herbaceous peony flower extracts for $24 \mathrm{~h}$. Cell viability was determined by MTT assay. *: $p$ $<0.05$ and $* *: p<0.01$ compared to c@ontrol 
$\alpha$-Glucosidase inhibition: Inhibitors of intestinal $\alpha$-glucosidase are used in the treatment of non-insulin-dependent diabetes mellitus (NIDDM) and represent a huge proportion of the antidiabetic drug market ${ }^{31}$. It has been reported that the inhibition of $\alpha$-glucosidase reduces the bioavailability of glucose, the determination of 40 drugs that inhibit carbohydrate hydrolyzing enzymes have been proved to decrease postprandial hyperglycemia and improve impaired glucose metabolism without promoting insulin secretion in NIDDM patients. To determine if herbaceous peony flower extracts possess antidiabetic properties, we studied the effect of these extracts in $\alpha$-glucosidase inhibition assays. All the extracts demonstrated $\alpha$-glucosidase inhibitory activity (Table-2). Based on the calculated $\mathrm{IC}_{50}$ values, PEF $(21.98 \pm 0.55 \mu \mathrm{g} / \mathrm{mL})$ and EAF $(33.84 \pm 0.78 \mu \mathrm{g} / \mathrm{mL})$ showed the highest activity, followed by $\mathrm{EEF}(141.46 \pm 1.23 \mu \mathrm{g} / \mathrm{mL}), \mathrm{BF}(213.12 \pm 2.11$ $\mu \mathrm{g} / \mathrm{mL})$ and $\mathrm{WF}(244.77 \pm 2.98 \mu \mathrm{g} / \mathrm{mL})$. The extracts of herbaceous peony flower had $\alpha$-glucosidase inhibitory activity, showing that they contain effective $\alpha$-glucosidase inhibitors that may have potential antidiabetic activity.

\begin{tabular}{cc} 
TABLE-2 \\
EFFECTS OF DIFFERENT EXTRACTS OF \\
HERBACEOUS PEONY ON RAT INTESTINAL \\
\multicolumn{2}{c}{$\alpha$-GLUCOSIDASE INHIBITION ASSAY } \\
\hline Sample & $\alpha$-Glucosidase inhibitory activity $\left(\mathrm{IC}_{50}{ }^{\mathrm{a}} \mu \mathrm{g} / \mathrm{mL}\right)$ \\
\hline PEF & $21.98 \pm 0.55^{\mathrm{b}}$ \\
EEF & $141.46 \pm 1.23$ \\
EAF & $33.84 \pm 0.78$ \\
BF & $213.12 \pm 2.11$ \\
WF & $244.77 \pm 2.98$ \\
Acarbose & $0.003 \pm 0.01$ \\
\hline
\end{tabular}

${ }^{a}$ Amount required for $50 \%$ inhibition. ${ }^{b}$ Values represent the mean \pm $\mathrm{SD}(\mathrm{n}=3)$

\section{Conclusion}

In this study, the extracts from herbaceous peony flower showed different biological activities. The herbaceous peony flower extracts showed higher phenolic, free radical scavenging, antiinflammatory and anti $\alpha$-glucosidase activities. These results suggest that herbaceous peony flower be investigated for further research of its antioxidant and antidiabetes activity. The mechanisms of antiinflammatory effect elicited by ethyl ether fraction and ethyl acetate fraction will be explored in further studies.

\section{ACKNOWLEDGEMENTS}

This work was financially supported by Agricultural Science \& Technology Independent Innovation Fund of Jiangsu Province CX(12)2019, P.R. China.

\section{REFERENCES}

1. A. Braca, P.V. Kiem, P.H. Yen, N.X. Nhiem, T.H. Quang, N.X. Cuong and C.V. Minh, Fitoterapia, 79, 117 (2008).

2. N. Kim, K.R. Park, I.S. Park and Y.H. Park, Food Chem., 96, 496 (2006).

3. H.B. Wang, W.F. Gu, W.J. Chu, S. Zhang, X.C. Tang and G.W. Qin, J. Nat. Prod., 72, 1321 (2009).

4. A. Ikuta, K. Kamiya, T. Satake and Y. Saiki, Phytochemistry, 38, 1203 (1995).

5. K. Kamiya, K. Yoshioka, Y. Saiki, A. Ikuta and T. Satake, Phytochemistry, 44, 141 (1997).

6. N. Jia, Q.Y. Shu, L.S. Wang, H. Du, Y.J. Xu and Z.A. Liu, Sci. Hortic., 117, 167 (2008).

7. H.J. Kim, E.J. Chang, S.J. Bae, S.M. Shim, H.D. Park, C.H. Rhee, J.H. Park and S.W. Choi, Arch. Pharm. Res., 25, 293 (2002).

8. N. Kumar and M.G. Motto, Phytochemistry, 25, 250 (1985).

9. D. Guo, G. Ye and H. Guo, Fitoterapia, 77, 613 (2006).

10. S.C. Lee, Y.S. Kwon, K.H. Son, H.P. Kim and M.Y. Heo, Arch. Pharm. Res., 28, 775 (2005).

11. F. Chen, H.T. Lu and Y. Jiang, J. Chromatogr. A, 1040, 205 (2004).

12. B. Lee, Y.W. Shin, E.A. Bae, S.J. Han, J.S. Kim, S.S. Kang and D.H. Kim, Arch. Pharm. Res., 31, 445 (2008).

13. L. Xiao, Y.Z. Wang, J. Liu, X.T. Luo, Y. Ye and X.Z. Zhu, Life Sci., 784, 413 (2005).

14. Y. Yang, T. Yu, H.J. Jang, S.E. Byeon, S.Y. Song, B.H. Lee, M.H. Rhee, T.W. Kim, J. Lee, S. Hong and J.Y. Cho, J. Ethnopharmacol., 139, 616 (2012).

15. P. McCue, Y.I. Kwon and M.K. Shetty, Asia Pacific J. Clin. Nutri., 14, 145 (2005)

16. T.L. Shale, W.A. Stirk and J. Staden, J. Ethnopharmacol., 67, 347 (1999).

17. R.R. Baumgartner, D. Steinmann, E.H. Heiss, A.G. Atanasov, M. Ganzera, H. Stuppner and V.M. Dirsch, Nat. Prod., 73, 1578 (2010).

18. M.J. Jung, S.I. Heo and M.H. Wang, Food Chem., 108, 482 (2008).

19. P. Prieto, M. Pineda and M. Aguilar, Anal. Biochem., 269, 337 (1999).

20. S. Kilani, R.B. Ammar, I. Bouhlel, A. Abdelwahed, N. Hayder, A. Mahmoud, K. Ghedira and L. Chekir-Ghedira, Environ. Toxicol. Pharmacol., 20, 478 (2005).

21. W. Hu, T. Shen and M.H. Wang, J. Food Sci. Nutr., 14, 277 (2009).

22. Y.M. Kim, M.H. Wang and H.I. Rhee, Carbohydr. Res., 339, 715 (2004).

23. J.Y. Cho, K.U. Baik, J.H. Jung and M.H. Park, Eur. J. Pharmacol., 398, 399 (2000).

24. D.B. Choi, S.S. Park, J.L. Ding and W.S. Cha, Biotechonol. Bioprocess Eng., 12, 516 (2007).

25. D. Steinberg, J. Internal. Med., 233, 227 (1993).

26. K. Shimada, K. Fujikawa, K. Yahara and T. Nakamura, J. Agric. Food Chem., 40, 945 (1997).

27. E.R. Stadtman and R.L. Levin, Ann. NY Acad. Sci., 899, 191 (2000).

28. L. Ferrero-Miliani, O.H. Nielsen, P.S. Andersen and S.E. Girardin, Clin. Exp. Immunol., 147, 227 (2007).

29. P.O. Osadebe and F.B.C. Okoye, J. Ethnopharmacol., 89, 19 (2003).

30. C. Nicholas, S. Batra, M.A. Vargo, O.H. Voss, M.A. Gavrilin, M.D. Wewers, D.C. Guttridge, E. Grotewold and A.I. Doseff, J. Immunol., 179, 7121 (2007).

31. S.E. Inzucchi, J. Am. Med. Assoc., 287, 360 (2002), 